\title{
Glycollate concentrations in relation to hydrography in Liverpool Bay
}

\author{
R. H. Al-Hasan ${ }^{1} \&$ G. E. Fogg ${ }^{2}$ \\ ' Department of Botany and Microbiology, Kuwait University, PO Box 5969, Kuwait \\ ${ }^{2}$ School of Ocean Sciences (University College of North Wales), Marine Science Laboratories, Menai Bridge, Gwynedd LL59 5EH, United \\ Kingdom
}

ABSTRACT: Determinations of glycollate in surface waters in a frontal region in Liverpool Bay showed higher concentrations in stratified than in mixed water columns.

The simple view that the release of glycollate by phytoplankton is an overflow of excess photosynthetic product is in general agreement with observed facts. Thus saturating irradiance and deficiency of mineral nutrients both favour the liberation in this form of a high proportion of the total carbon assimilated (for review see Fogg 1983). One might therefore expect that in a well-mixed water column, in which nutrient concentrations are adequate but the average irradiance reaching the cells limiting, less glycollate would be released by phytoplankton than in the surface waters of a stratified area, where the cells may be exposed to excess irradiance and nutrients depleted. This expectation seems to be borne out by the observations of Shailaja \& Pant (1986), who found that in a tropical estuary the proportion of glycollate in extracellular products in surface samples was about 10 times higher in the pre-monsoon period, when conditions were calm and the entire water column was within the euphotic zone, than during the monsoon when the sky was overcast and the waters of the bay turbulent. A frontal situation, in which stratified and mixed waters are present alongside each other at the same time, provides another sort of opportunity to test this hypothesis. The results reported in this note were obtained in the course of a general study of the frontal system in Liverpool Bay, Irish Sea (Floodgate et al. 1981, Foster et al. 1982).

Methods. Observations were made at the stations shown in Fig. 1 during a cruise of R. V. Prince Madog in September 1978. Surface variations of salinity and temperature were monitored continuously (Foster et al. 1977). At stations, samples were taken from $0.5 \mathrm{~m}$ depth with National Institute of Oceanography (NIO) bottles. Pigment analyses were carried out according to Parsons \& Strickland (1965) and glycollate was determined by the method of Shah \& Wright (1974). In Table 1 the standard deviations attached to the glycollate values were each calculated from a regression based on 8 measurements made with graded additions of glycollate as standards. Primary productivity data, obtained at the same stations with similar samples using a ship-board radiocarbon technique (Beardall et al. 1982), together with phytoplankton counts, were kindly provided by Dr. J. Beardall.

Results. From Table 1 it will be seen that glycollate concentrations in Liverpool Bay varied between about 15 and $61 \mu \mathrm{g} \mathrm{l}^{-1}$. These may be compared with 0 to 60 $\mu \mathrm{gl}^{-1}$ found in the adjacent Menai Straits (Al-Hasan et al. 1975), 20 to $42 \mu \mathrm{g} \mathrm{l}^{-1}$ in Ipswich Bay, Massachusetts, USA (Wright \& Shah 1975), 68 to $342 \mu \mathrm{g} \mathrm{l}^{-1}$ in Belgian coastal waters and English Channel (Billen et al. 1980) and 160 to $180 \mu \mathrm{g} \mathrm{l}^{-1}$ in Dona Paula Bay, Goa (Shailaja \& Pant 1986). If the seasonal periodicity in Liverpool Bay in 1978 was similar to that in the Menai Straits in 1973 and 1974 (Al-Hasan et al. 1975) then glycollate concentrations were near their maximum at the time of our observations. The concentrations did not show any consistent relation to phytoplankton biomass (in terms of chlorophyll) photosynthetic capacity or species compasition. Coughlan \& Al-Hasan (1977)-found a diel variation in glycollate concentration in the Menai Straits with a peak around noon and values falling to about half that level during the night but, although some samples were taken in the day and others at night, there is no evident diel periodicity in our results. On the other hand, there does seem to be some effect of hydrographic structure on glycollate concentration.

The plume front in Liverpool Bay, although intermittent, usually lies along the $4^{\circ} \mathrm{W}$ meridian with mixed, 


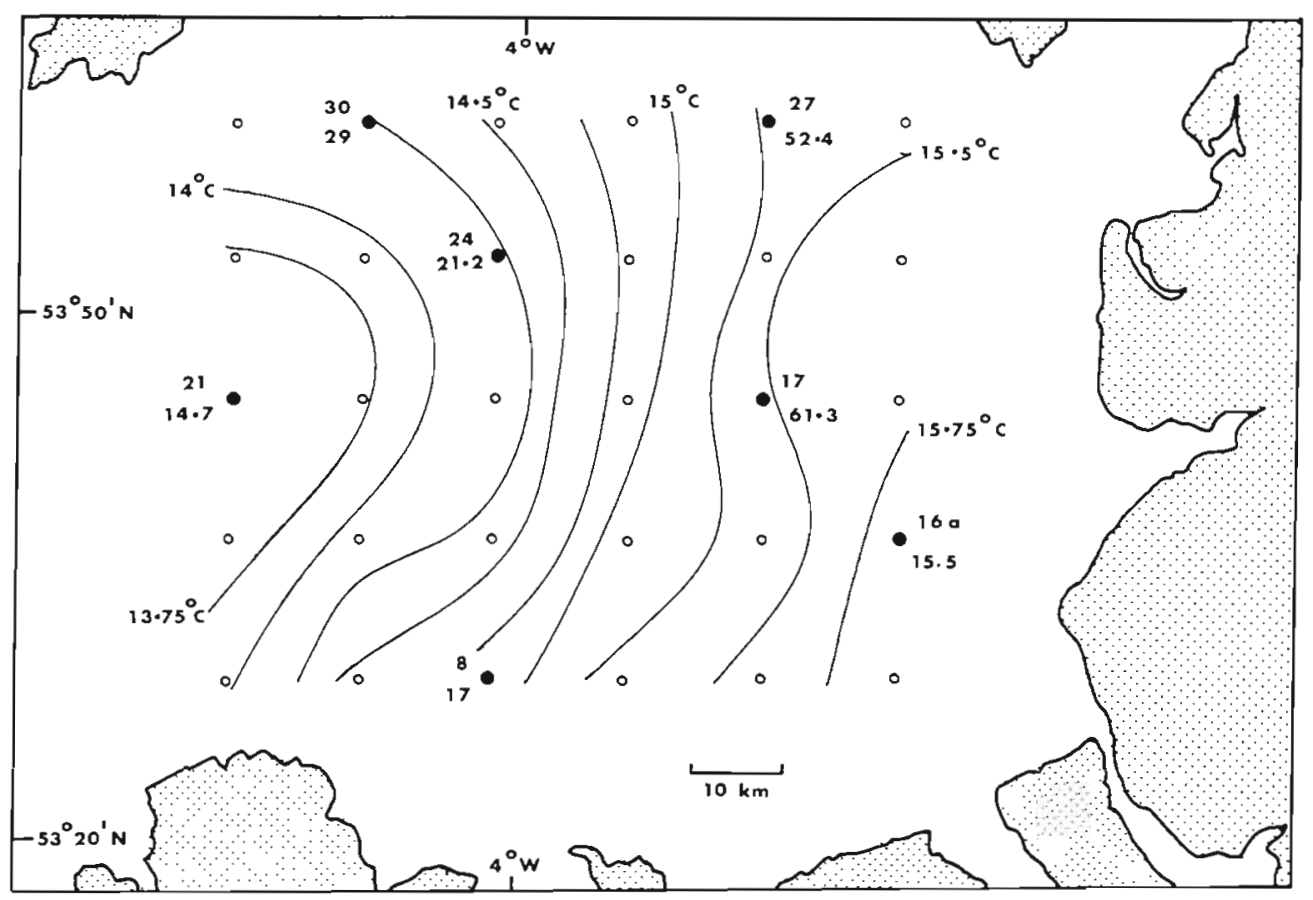

Fig. 1. Liverpool Bay (Irish Sea) showing positions of sampling stations and surface temperatures on 6 to 8 Sep 1978 . Stations at which glycollate determinations were made are denoted by solid circles, the adjacent upper figure being the station number and the lower the glycollate concentration in $\mu \mathrm{g} \mathrm{I}^{-1}$

fully marine, water to the west and stratified water, stabilized by freshwater input and, in the summer, solar heating, to the east (for further details see Floodgate et al. 1981, Foster et al. 1982, Fogg et al. 1985). At the time of our investigation the front was not clearly demarcated but our stations included both mixed and stratified areas in expected positions, as shown by the temperature and salinity data (Table 1). Thus stations to the east - Stns $16 a, 17$ and 27 - were characterized by higher temperatures and lower salinities in their surface waters, whereas those to the west - Stns 8,21 , 24 and 30 - had lower temperatures and higher salinities. The 3 more easterly stations had standing stocks of phytoplankton several-fold more dense than those to the west, in accordance with high nutrient concentrations established in the stratified area at the

Table 1. Concentrations of glycollate in relation to physical factors and phytoplankton abundance and activity in Liverpool Bay, 6 to 8 Sep 1978. For positions of stations see Fig. 1. Phytoplankton composition is expressed in percentage of total numbers of individual cells contributed by diatoms, dinoflagellates and other flagellates

\begin{tabular}{|c|c|c|c|c|c|c|c|c|c|c|}
\hline \multirow[t]{2}{*}{ Stn } & \multirow{2}{*}{$\begin{array}{l}\text { Date } \\
(1978) \\
\text { \& time }\end{array}$} & \multirow[t]{2}{*}{$\begin{array}{c}\text { Temp. } \\
\left({ }^{\circ} \mathrm{C}\right)\end{array}$} & \multirow[t]{2}{*}{$\begin{array}{c}\text { Salinity } \\
(\% 0)\end{array}$} & \multirow[t]{2}{*}{$\begin{array}{c}\text { Glycollate } \\
\left(\mu \mathrm{g} \mathrm{I}^{-1}\right)\end{array}$} & \multirow[t]{2}{*}{$\begin{array}{l}\text { Chlorophyll } \\
\left(\mu \mathrm{g} \mathrm{l}^{-1}\right)\end{array}$} & \multirow[t]{2}{*}{$\begin{array}{l}\text { Primary prod. } \\
\left(\mu \mathrm{g} C \mathrm{I}^{-1} \mathrm{~h}^{-1}\right)\end{array}$} & \multirow{2}{*}{$\begin{array}{c}\text { Ps. capacity } \\
\left(\mu \mathrm{g} \mathrm{C}[\mu \mathrm{g} C h l]^{-1}\right. \\
\left.\mathrm{h}^{-1}\right)\end{array}$} & \multicolumn{3}{|c|}{$\begin{array}{l}\text { Phytoplankton } \\
\text { composition }(\%)\end{array}$} \\
\hline & & & & & & & & Diat. & Dino. & Flag. \\
\hline 17 & $\begin{array}{l}6 \text { Sep } \\
1012 \mathrm{~h}\end{array}$ & 15.53 & 33.16 & $61.3 \pm 8.69$ & 5.63 & 43.7 & 7.8 & 18 & 27 & 49 \\
\hline 21 & $\begin{array}{l}6 \mathrm{Sep} \\
1610 \mathrm{~h}\end{array}$ & 13.55 & 34.32 & $14.7 \pm 8.67$ & 0.90 & 12.2 & 13.6 & 16 & 1 & 78 \\
\hline 24 & $\begin{array}{l}7 \text { Sep } \\
1232 \mathrm{~h}\end{array}$ & 14.28 & 34.12 & $21.2 \pm 6.65$ & 0.70 & 51.2 & 73.1 & 6 & 13 & 79 \\
\hline 27 & $\begin{array}{l}7 \text { Sep } \\
2034 \mathrm{~h}\end{array}$ & 15.38 & 33.43 & $52.4 \pm 18.17$ & 3.80 & 103.6 & 27.3 & 3 & 16 & 81 \\
\hline 30 & $\begin{array}{l}8 \mathrm{Sep} \\
0036 \mathrm{~h}\end{array}$ & 14.30 & 34.05 & $29.0 \pm 10.07$ & 0.55 & 5.5 & 10.0 & 3 & 12 & 81 \\
\hline $16 a$ & $\begin{array}{l}8 \text { Sep } \\
0540 \mathrm{~h}\end{array}$ & 15.86 & 32.93 & $15.5 \pm 4.04$ & 4.05 & 9.6 & 2.4 & 11 & 28 & 62 \\
\hline 8 & $\begin{array}{l}8 \mathrm{Sep} \\
0828 \mathrm{~h}\end{array}$ & 14.82 & 33.70 & $17.0 \pm 4.05$ & 1.30 & 12.5 & 9.6 & 26 & 5 & 65 \\
\hline
\end{tabular}


beginning of the season by freshwater input (Foster et al. 1982). The 2 most northerly stratified stations, Stns 17 and 27 , both had high concentrations of glycollate whereas elsewhere concentrations were lower. While that at $\operatorname{Stn} 27$ was not actually statistically different from that at its neighbour due west, $\operatorname{Stn} 30$ (d = $23.4 \pm$ 20.77, $\mathrm{t}=1.13, \mathrm{p} \sim 0.3)$, the concentration at Stn 17 was significantly different from those at the 2 stations to its west, $\operatorname{Stn} 8(\mathrm{~d}=43.3 \pm 9.59, \mathrm{t}=4.52, \mathrm{p}<0.001)$ and $\operatorname{Stn} 24(\mathrm{~d}=40.1 \pm 10.94, \mathrm{t}=3.66, \mathrm{p}<0.01)$. The most easterly station, Stn $16 \mathrm{a}$, had a low glycollate concentration although it was in the stratified area. However, it was sampled at the end of the night and it may have been that high heterotrophic activity associated with river inflow (Floodgate et al. 1981) had removed much of the glycollate which had been present the previous evening. It may also be noted that this station, although it had a dense phytoplankton population, showed the lowest photosynthetic capacity of those sampled.

Discussion. It seems unlikely that high glycollate concentrations could be due to input from rivers. We know of no data on glycollate concentrations in river waters but the station (16a) most subject to freshwater influence had one of the lowest concentrations of this substance. There may sometimes be a correlation of glycollate concentations with phytoplankton biomass (Al-Hasan et al. 1975) and the 2 stations at which we found the highest glycollate concentrations also had high chlorophyll a concentrations. Nevertheless, there is no overall correlation of glycollate and chlorophyll concentrations to be seen in our data and it is well established that high irradiance is a dominant factor determining glycollate release (Fogg 1983). We therefore suggest that the higher concentrations of glycollate at the stratified stations resulted from a greater rate of release from phytoplankton exposed to effectively higher irradiances and lower nutrient concentrations than was phytoplankton in the mixed water. It is likely that silicate would have been the main limiting nutrient in Liverpool Bay at this time (Foster et al. 1982). These findings thus give substance to the suggestion of Fogg et al. (1985) that the greater heterotrophic activity found on the stratified, as compared with the mixed side, of a front is supported by increased release of extracellular products of phytoplankton photosynthesis.

\section{LITERATURE CITED}

Al-Hasan, R. H., Coughlan, S. J., Pant, A., Fogg, G. E. (1975). Seasonal variations in phytoplankton and glycollate concentrations in the Menai Straits, Anglesey. J. mar. biol. Ass. U. K. 55: 557-565

Beardall, J., Foster, P., Voltolina, D., Savidge, G. (1982). Observations on the surface water characteristics in the western Irish Sea: July 1977. Estuar. coast. Shelf Sci. 14: 589-598

Billen, G., Joiris, C., Wijnant, J., Gillain, G. (1980). Concentration and microbiological utilization of small organic molecules in the Scheldt estuary, the Belgian coastal zone of the North Sea and the English Channel. Estuar. coast. mar. Sci. 11: 279-294

Coughlan, S. J., Al-Hasan, R. H. (1977). Studies of uptake and turnover of glycollic acid in the Menai Straits, North Wales. J. Ecol. 65: 731-746

Floodgate, G. D., Fogg, G. E., Jones, D. A., Lochte, K., Turley, C. M. (1981). Microbiological and zooplankton activity at a front in Liverpool Bay. Nature, Lond. 290: 133-136

Fogg, G. E. (1983) The ecological significance of extracellular products of phytoplankton photosynthesis. Botanica mar. 26: 3-14

Fogg, G. E., Egan, B., Floodgate, G. D., Jones, D. A., Kassab, J. Y., Lochte, K., Rees, E. I. S., Scrope-Howe, S., Turley, C. M. (1985) Biological studies in the vicinity of a shallowsea tidal mixing front. VII. The frontal ecosystems. Phil. Trans. R. Soc. B 310: 555-571

Foster, P., Pugh, K. B., Hunt, D. T. E., Foster, G. M., Savidge, G. (1977). A seasonal study of the distributions of surface state variables in Liverpool Bay. I. Winter data. J. exp. mar. Biol. Ecol. 29: 303-313

Foster, P., Voltolina, D., Spencer, C. P., Miller, I., Beardall, J. (1982). A seasonal study of the distributions of surface state variables in Liverpool Bay. III. An offshore front. J. exp. mar. Biol. Ecol. 58: 19-31

Parsons, T. R., Strickland, J. D. H. (1965). Particulate organic matter. III. I Pigment analysis. III.I.I Determination of phytoplankton pigments. J. Fish. Res. Bd Can. 18: 117-127

Shah, N. M., Wright, R. T. (1974). The occurrence of glycollic acid in coastal sea water. Mar. Biol. 24: 121-124

Shailaja, M. S., Pant, A. (1986). Relationship between particulate and extracellular carbon compounds of phytoplankton photosynthesis in a tropical estuary. Mar. Ecol. Prog. Ser. 32: 161-167

Wright, R. T., Shah, N. M. (1975). The trophic role of glycolic acid in coastal seawater. I. Heterotrophic metabolism in seawater and bacterial cultures. Mar. Biol. 33: 175-183 